Mackay, A.D.; Lambert, M.G. 2011. Long-term changes in soil fertility and pasture production under no, low and high phosphorus fertiliser inputs. Proceedings of the New Zealand Grassland Association 73: 37-42. Sears, P.D. 1960. Grass/clover relationships in New Zealand. Proceedings of the $13^{\text {th }}$ International Grassland Congress: 130-133.

Williams, W.M.; Lambert, M.G.; Caradus, J.R. 1982.
Performance of a hill country white clover selection. Proceedings of the New Zealand Grassland Association 43: 188-195.

Williams, W.M.; Sheath, G.W.; Chapman, D.F. 1990 Evaluation of clovers in dry hill country. 1. General objectives and description of sites and plant material. New Zealand Journal of Agricultural Research 33: 521-526.

\title{
Sediment and nutrient losses under winter cropping on two Manawatu hill country soils
}

L.L. BURKITT ${ }^{1}$, J.L. WINTERS ${ }^{2}$ and D.J. HORNE ${ }^{\prime}$ Fertilizer and Lime Research Centre, Massey University, Private Bag 11222, Palmerston North, 4442, New Zealand ${ }^{2}$ Greater Wellington Regional Council, 34 Chapel St, Masterton 5810, New Zealand

L.Burkitt@massey.ac.nz

\section{Abstract}

Aerial spraying and surface seeding of winter crops in uncultivable hill country areas is rapidly being adopted as a method of increasing winter feed supply and as a precursor to regrassing. However, there is little research on the sediment and nutrient losses that may result from this practice. In the current study, winter swede crops were established on an imperfectly and on a welldrained soil and these crops were grazed by beef cattle. Soil damage caused by the winter grazing of the swedes generated sediment losses that were 5.5 times greater on the imperfectly drained soil than the well-drained soil. Surface runoff over 3 months (which included crop grazing and the non-grazed crop stubble period) resulted in losses of $1.1 \mathrm{t} / \mathrm{ha}$ of sediment, $0.85 \mathrm{~kg}$ of phosphorus $(\mathrm{P}) / \mathrm{ha}$ and $5.4 \mathrm{~kg}$ of nitrogen $(\mathrm{N}) / \mathrm{ha}$ from the poorly drained soil. This key risk period contributed between 88 and $99 \%$ of the total annual sediment and total $\mathrm{N}$ and $\mathrm{P}$ losses, compared to the pre-crop (pasture) and crop establishment phase. A simple comparison with two other sediment and nutrient loss studies located on the same farm as the current study, suggested that the losses associated with winter cropping in this landscape may be extreme. The current study highlights the need for targeted mitigation strategies and/or strategic grazing management to reduce soil and nutrient losses and to minimise the impacts on waterways of winter grazing of hill country crops.

Keywords: winter cropping, hill country, surface runoff, sediment losses, nutrient losses

\section{Introduction}

In an effort to boost dry matter production and improve animal performance, more sheep and beef farmers are sowing crops on uncultivable hill country slopes using helicopter spraying and seeding. Despite the increase in the area of hill country that is used to grow crops, there is currently little research on the sediment and nutrient losses that may result from this practice. This is a major concern as these crops are often grown on slopes of $\geq 20^{\circ}$ and the processes of spraying out existing pasture exposes bare soil.

Although studied in a semi-arid environment on shallower slopes $\left(<5^{\circ}\right)$, Silburn et al. (2011) reported that runoff volume and suspended sediment load increased with increasing slope, but decreased exponentially as ground cover increased. Subsequen winter grazing increases the risk of treading damage, soil erosion and nutrient loss. Soil physical damage associated with treading damage and cultivation have been shown to increase sediment and nutrient losses in plot-scale and small-scale rainfall simulation studies (e. Nguyen et al. 1998; McDowell et al. 2003b), but

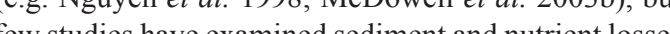
following winter crop grazing. McDowell et al. (2003a) measured greater concentrations of sediment and losses in surface runoff following grazing in a plotscale study with pasture, cultivated crop, and cultivated crop (grazed) treatments on slopes $<11^{\circ}$ in South Otago. Orchiston et al. (2013) compared sediment and $\mathrm{P}$ loss using conventional and strategic grazing echniques for winter crops, also in South Otago. The involved grazing dairy cattle in (he paddock first and the trip-grazing upwards with no back fencing and with free access to gully and swale areas, known as critical source areas (CSA). In the strategic method, dairy cattle strip-grazed from the top of the catchment in the downslope direction using back-fencing, and CSA's were fenced off and only grazed if soil conditions were suitable. Orchiston et al. (2013) reported sediment and tol $\mathrm{P}$ losses following strategic grazing were only 10 $20 \%$ of those meas and $20 \%$ of tose measred ung crop grazing approach. Another sub-catchment study examining the effect of winter crop grazing by dairy cattle on stream water quality (McDowell 2006) showed that crop grazing had minimal impact on P loss, but increased average suspended sediment loss by $75 \%$. Although these New Zealand studies provide insight with regard to sediment and nutrient losses following the grazing of winter crops, research to date has focussed cultivatable rolling land used for dairy production. There has been no research quantifying sediment an nutrient losses from hill country cropping, despite it being undertaken on steeper land (slopes of $\geq 20^{\circ}$ ) without cultivation. The objectives of the current study was to 1) quantify sediment and nutrient loss in surface runoff from a surface sown hill country winter swede crop which was grazed conventionally and 2) compare 


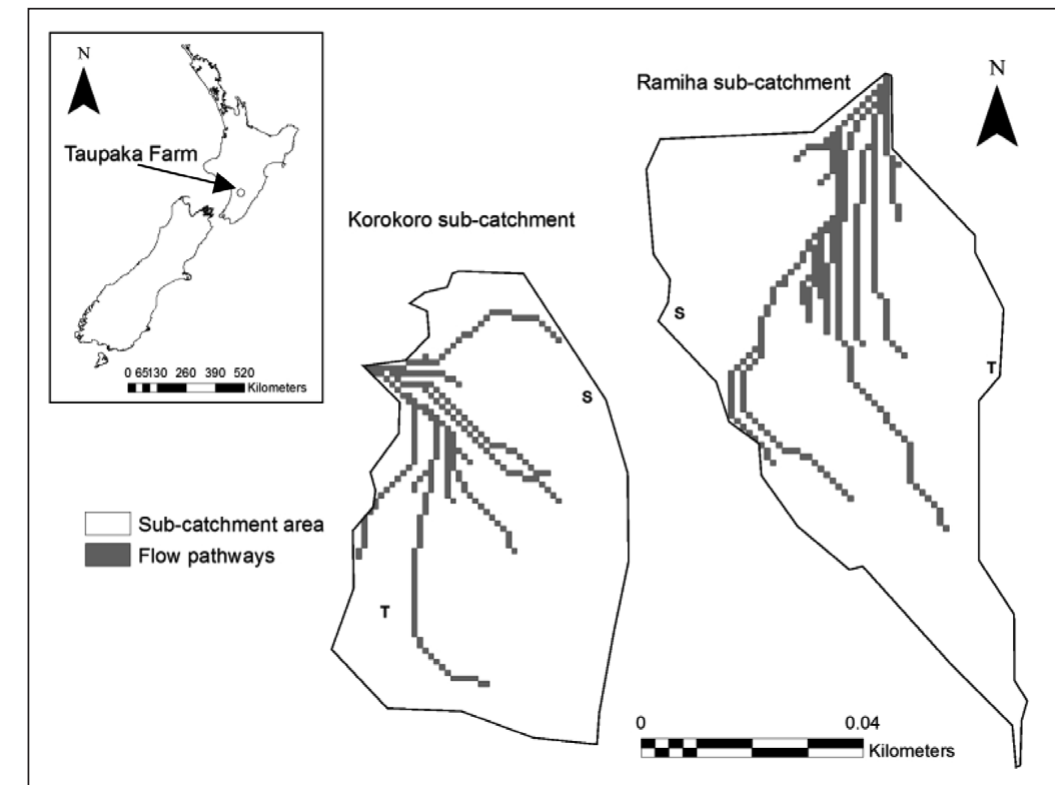

Figure 1 Location of the two study sub-catchments on Massey University's Tuapaka Agricultural Experiment Station, North Island, New Zealand. T denotes the position
of the water trough and $S$ denotes the position of silage bales within the subcatchment area.

sediment and nutrient losses as a result of hill country cropping from two different soil types; an imperfectly drained and a well-drained soil.

\section{Methods}

Experimental sites

The study area was located at Massey University's Tuapaka Agricultural Experiment Station located 15 $\mathrm{km}$ northwest of Palmerston North, New Zealand $\left(-40.355175^{\circ} 175.738271^{\circ}\right)$. Tuapaka has an average rainfall of $1100 \mathrm{~mm} / \mathrm{year}$ and an altitude range of 100-360 m a.s.1. Two small sub-catchments (Figure 1) were selected for the study using a $1 \mathrm{~m}$ LiDAR digital elevation model to define flow pathways, slopes and the catchment areas. The Korokoro site had slopes ranging from $2-24^{\circ}$ with a catchment area of 0.33 ha, wherea slopes at the Ramiha site ranged from $0-28^{\circ}$ with a catchment area of 0.36 ha. The sub-catchments were located $<350 \mathrm{~m}$ from each other.

The sub-catchments were selected on the basis of contrasting soil types. The Korokoro sub-catchment has an imperfectly drained soil (silt loam topsoil above a clay loam sub-soil) that increases in density with depth. Stones are present in the surface of the Korokoro soil profile. The Ramiha sub-catchment has well-drained soil with a silt loam topsoil and friable soil structure. Due to tephra deposits, the anion storage capacity (ASC) was greater in the Ramiha soil (57\%) than the Korokoro soil (32\%) (Table 1). Compared to the
Ramiha sub-catchment, the Korokoro sub-catchment was slightly more acidic, had lower cation exchange capacity, a lower sulphate sulphur concentration, and had a higher Olsen $\mathrm{P}$ and potassium concentrations, associated with previous use as a supplement feeding area (Table 1).

\section{Crop establishmen}

Due to difficult landscape features such as steep banks and a deep hole, not all of the sub-catchment area was able to be sown to swedes; these areas remained in pasture. The cropped area made up 0.22 ha of the Korokoro and 0.33 ha of the Ramiha subcatchment $(67$ and $92 \%$ of the total sub-catchment areas, respectively). Permanent pasture in the two subcatchmentswas spayedouton 14November 2015 using a mixture $4 \mathrm{~L} / \mathrm{h}$ of a mixture of $4 \mathrm{~L} /$ ha of glyphosate (WeedMaster ${ }^{\mathbb{B}} \mathrm{TS} 540$ ), $500), 400$ $\mathrm{ml} / \mathrm{ha}$ of an insecticide (Dew ${ }^{\mathrm{TM}} 600$ ) and $250 \mathrm{ml} / \mathrm{ha}$ of a penetrant (Pulse ${ }^{\circledR}$ Penetrant). The areas were sown on 30 November 2015 with $2.5 \mathrm{~kg} / \mathrm{ha}$ of Domain Swede (treated with a polymer to reduce dusting) and $5 \mathrm{~kg}$ / ha of Mesurol ${ }^{\mathbb{B}}$ Pro slug bait using hand-held fertiliser spreaders. Seed was spread on to the surface of the soil, with no cultivation. At larger scales, herbicide,

Table 1 Soil chemical properties of the Korokoro and Soil chemical properties of the Korokoro and
Ramiha sub-catchments, sampled to a depth of 7.5 $\mathrm{cm}$.

Analysis

Korokoro Ramina $\mathrm{pH}\left(1: 2 \mathrm{H}_{2} \mathrm{O}\right)$

$5.1 \quad 5.3$

5.1

5.3

Potassium $(\mathrm{me} / 100 \mathrm{~g})^{\mathrm{A}}$

20

Anion storage capacity (\%)

1.35

0.78

CEC (me/100g)

Sulphate sulphur $(\mathrm{mg} / \mathrm{kg})$

32
22

45
45

Total carbon (\%) ${ }^{\mathrm{C}}$

$4.7 \quad 53$

1 M Neutral ammonium acetate extraction followed by ICP-OES B Blakemore et al. (1972)
C Determined by (1R, calibration based on total carbon by Dumas by helicopter. Additionally, $250 \mathrm{~kg} / \mathrm{ha}$ of Cropmaster DAP (17.6:20:0:1) fertiliser was applied at sowing. Ideally, the seed would have been pushed into the soil using a mob of sheep or a roller, but these options were not available at this time. In December 2015, the two cropped areas were sprayed with $350 \mathrm{ml} /$ ha of a broadleaf weed herbicide Radiate $^{\mathrm{TM}}$ and $1 \mathrm{~L} /$ ha of a penetrant (Pulse ${ }^{\mathbb{P}}$ Penetrant) to control weed infestation. In March 2016, $250 \mathrm{~kg}$ /ha of Cropmaster DAP (17.6:20:0:1) fertiliser was surface applied.

Crop yield

In February 2016, crop germination was measured by counting the number of plants within $1 \mathrm{~m}^{2}$ in 20 randomly selected positions across the sub-catchment. Immediately before grazing, final crop yield was assessed by harvesting all of the plant material within 10 randomly positioned quadrants $(87 \times 40 \mathrm{~cm})$ for each sub-catchment. Swede and weedpasture plan material was separated and weighed wet, then dried for $1-2$ weeks at $70^{\circ} \mathrm{C}$, before weighing.

\section{Crop grazing}

Due to the small size of the cropped areas, the subcatchments were grazed in two halves starting on 15 July 2016 using 17 (Korokoro sub-catchment) and 16 (Ramiha sub-catchment) Charolais steers. Water troughs were installed along the fence line and baled silage was provided ad lib inside the sub-catchment area (Figure 1). The crop was grazed using a conventional grazing method. Cattle grazed the bottom half of the catchment first and were then allowed access to the upper half. The cattle grazed each half of the Korokoro sub-catchment for 5 days, whereas they grazed the first half of the Ramiha sub-catchment for 5 days and the second half for 7 days, with no back-fence. Grazing time was set according to the farm managers observations of crop utilisation and cattle satiety.

\section{Surface runoff}

Guttering was installed at the bottom of the subcatchments to collect all surface runoff which fell within the sub-catchments (cropped and pasture areas) and to direct this runoff into a tipping bucket system which recorded the number of tips using a manual counter. Buckets were previously calibrated to allow runoff volume to be calculated based on the recorded number of tips. A composite sample was collected from each surface runoff event in a $20 \mathrm{~L}$ sampling containe hat were collected from the site as soon as practica after a runoff event (usually within 24 hours). Filtered $(<0.45 \mu \mathrm{m})$ water samples were analysed for dissolved reactive $\mathrm{P}$ (DRP), nitrate- $\mathrm{N}$ and ammonium- $\mathrm{N}$, and unfiltered samples were analysed for total $\mathrm{P}$ and total N colourmetrically using a Technicon Auto Analyser (Hosomi \& Sudo 1986). Suspended sedinent was ment was . hat were oven-dried at $105^{\circ} \mathrm{C}$ for 24 hours. Dry weight was recorded and the sample was filtered. Filters were then dried at $105^{\circ} \mathrm{C}$ for 24 hours and reweighed. The firs runoff event for the monitoring period was measured on 24 October 2015 and the last on 10 October 2016, with a total of 16 runoff events over this period.

The soil surface cover during the runoff monitoring period included GP: grazed pastures, NGC: non-grazed crop (during crop establishment), GC: grazed crop and NGCS: non-grazed crop stubble, allowing a comparison of sediment and nutrient losses over the different crop phases.

\section{Results and Discussion}

Crop yield

Despite having a slightly higher germination rate, the Ramiha sub-catchment had a slightly lower total swede yield than Korokoro (Table 2). This was likely due to reater infestation of pasture/weeds, possibly reducing swede growth and/or persistence over time. The total swede yield was 6.78 and $6.55 \mathrm{tDM} / \mathrm{ha}$ for the Korokoro and Ramiha sub-catchments, respectively. This yield was at the lower end of the 8-10 t DM/ha expected for this region $(\mathrm{H} \& \mathrm{~T}$ Agronomics field representatives pers. comm.). Given that the crops in the current study yield was considered acceptable.

\section{Crop grazing and soil damage}

The cattle readily grazed the swede tops, however they were initially reluctant to graze the bulbs, but this improved over time. Although the final swede crop utilisation was not measured, observations sugges that approximately $30-40 \%$ of the bulbs were not fully utilised. Visual observations suggested that soil damage

Table 2 Average germination rate and crop yield (t DM/ha) in each sub-catchment.

\begin{tabular}{lccccc}
\hline Sub-catchment & Swede germination & & \multicolumn{3}{c}{ Yield (t DM/ha) } \\
\cline { 2 - 4 } \cline { 5 - 6 } & (plants/ha) & & Pasture/weeds & Swedes & Total \\
\hline Korokoro & 201000 & & 0.88 & 6.78 & 7.66 \\
Ramiha & 214000 & & 1.34 & 6.55 & 7.89 \\
\hline
\end{tabular}




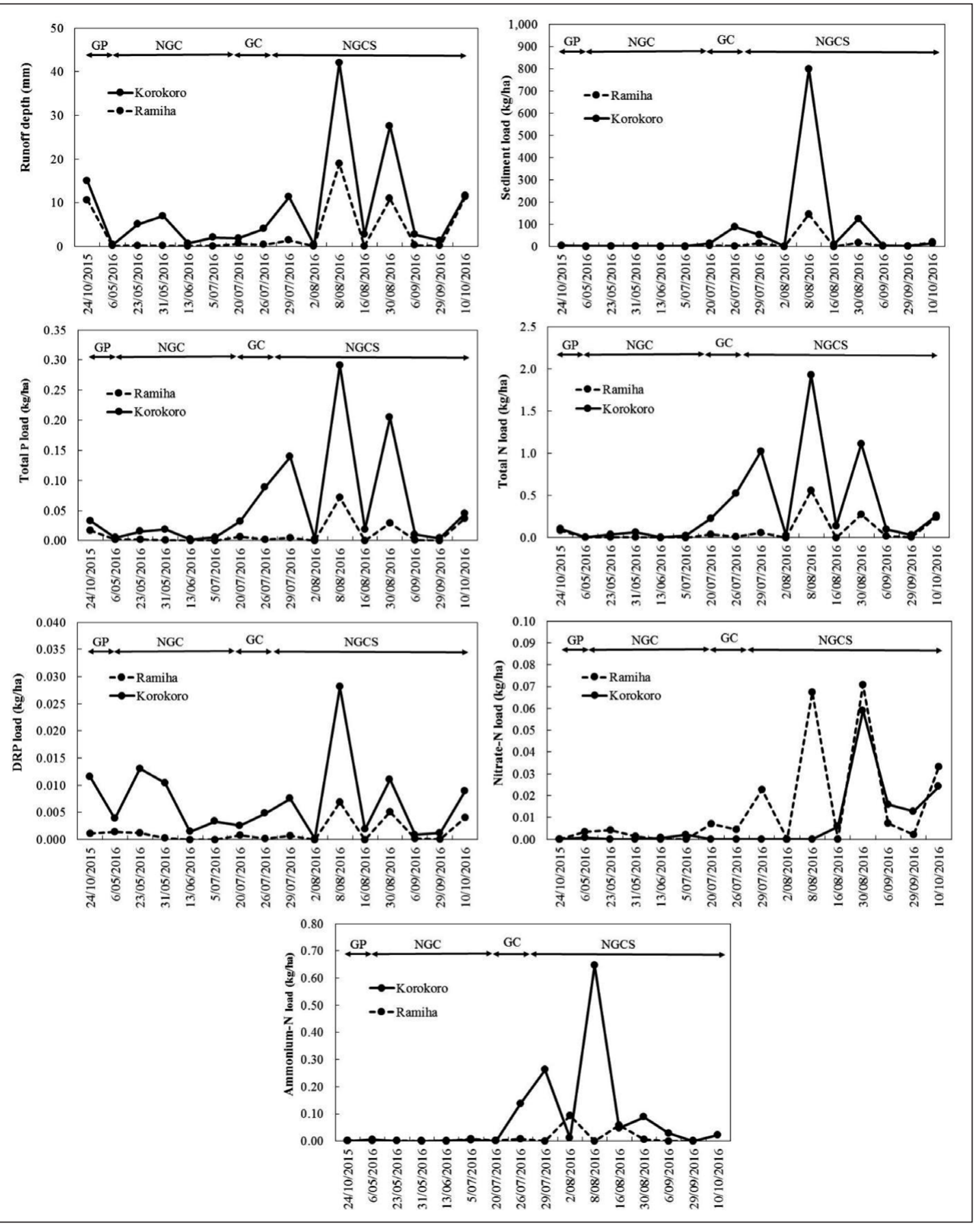

Figure 2 Depth of surface runoff ( $\mathrm{mm}$ ) and sediment and nutrient loads (kg/ha) in surface runoff from the Korokoro and Ramiha subincreased with the removal of ground cover and as grazing time increased. Severe treading damage was observed around the silage bale and water trough and this damage extended into the cropped area as ground cover diminished.

\section{Surface runoff volume and sediment and nutrient} loads

The depth of surface runoff from the imperfectly drained Korokoro soil was 2.5 times greater than that from the well-drained Ramiha soil, over the 1 year study (Table 3), a finding supported by Fransen et al. (2017). This difference in runoff depth contributed to greater annual sediment (5.5 times) and nutrient loads (5.4 times for total $\mathrm{P}$ and 4.3 times for total $\mathrm{N}$ ) from the Korokoro soil (Table 3) and highlights the risk of cropping on imperfectly drained soils. The Ramiha soil generated smaller quantities of runoff than the Korokoro soil due to its well-developed soil structure and intermediate texture throughout the profile, which enhance infltetion and dringe rates. The wreater ASC of the Remila soil was also likely to the surface soil profile, decreasing the amount of DRP lost in surface runoff, in comparison to the Korokoro soil. The slightly higher nitrate-N loads measured from the Ramiha sub-catchment from the non-grazed stubble phase were unexpected given that this soil is well drained (Table 3 ). The higher nitrate-N loads measured from the Ramiha sub-catchment, contrast with those reported by Fransen et al. (2017) and suggest that longer term data Ammorich Korokor sub-cich inet in reponse winter Korokos sub-catchment in response to winter grazing. This was not surprising as ammonium concentrations would have been elevated due to urine deposition following grazing and were more likely to be lost in surface runoff from the imperfectly drained Korokoro soil.

Large losses of sediment and nutrients were measured in runoff from the Korokoro soil over the 3 months which included the GC and NGCS phases: $1.1 \mathrm{t} / \mathrm{ha}$ of sediment, $0.83 \mathrm{~kg}$ of total P/ha and $5.38 \mathrm{~kg}$ of total $\mathrm{N} /$ ha (Table 3; Figure 2). In contrast, during the GP and NGC phases, only $7 \mathrm{~kg} / \mathrm{ha}$ of sediment,

0.08 of total $\mathrm{P} / \mathrm{ha}$ and $0.26 \mathrm{~kg}$ of total $\mathrm{N} / \mathrm{ha}$ were lost in surface runoff. In other words, the GC and NGC phases contributed between $91 \%$ and $99 \%$ of the total annual losses from the Korokoro soil. While losses of sediment and nutrients from the Ramiha soil were generally smaller, the percentage contribution of the GC and NGCS phases to overall annual losses were similar to those measured on the Korokoro soil (88 to $98 \%$ ). The suspended sediment loads measured in the current study were similar to those previously reported by Orchiston $e t$ al. (2013) (130 previllo 110 kga/year), but their highest total P loads ( $\sim 0.7$ to $\sim 4.5 \mathrm{~kg} / \mathrm{ha} /$ year) exceeded the total P losses measured in the current study (Table 3; Figure 2).

To place the magnitude of the sediment and nutrient losses during the GC and NGCS phases (88 days) in the current study in context, a comparison was made with the losses measured in recent studies conducted on the same or adjacent areas of Tuapaka farm, which included the soil types examined in the current study (Table 4). Burkitt et al. (2016) reported on annual sediment and nutrient loads leaving (via surface and subsurface flow) an 85 ha sub-catchment at Tuapaka farm in which the two small sub-catchments used in this study, were located. Fransen et al. (2017) measured sediment and nutrient runoff from grazed pasture from the same small sub-catchments used in the current study. In the Fransen et al. (2017) study, cattle were fed hay in the same position within each sub-catchment, which created pasture and treading damage, and runoff losses were measured over 43 days.

Although the Fransen et al. (2017) study was for only 43 days, comparable quantities of runoff were measured

Table 3 Surface runoff depth $(\mathrm{mm})$ and sediment and nutrient loads $(\mathrm{kg} / \mathrm{ha})$ resulting from establishment and grazing of a winter swede crop in hill country from October 2015 to October 2016.

\begin{tabular}{|c|c|c|c|c|c|c|c|}
\hline & \multirow[b]{2}{*}{ Depth (mm) } & \multicolumn{6}{|c|}{ Loads (kg/ha) } \\
\hline & & Sediment & Total P & Total $\mathbf{N}$ & DRP & Nitrate-N & Ammonium-N \\
\hline & & \multicolumn{6}{|c|}{ Grazed pasture (GP) and non-grazed crop (NGC) } \\
\hline Korokoro & 30 & 7 & 0.08 & 0.26 & 0.04 & 0.00 & 0.01 \\
\hline \multirow[t]{2}{*}{ Ramiha } & 11 & 4 & 0.02 & 0.10 & 0.00 & 0.01 & 0.00 \\
\hline & & \multicolumn{6}{|c|}{ Grazed crop (GC) } \\
\hline Korokoro & 5 & 104 & 0.12 & 0.75 & 0.01 & 0.00 & 0.14 \\
\hline \multirow[t]{2}{*}{ Ramiha } & 0.9 & 4 & 0.01 & 0.06 & 0.00 & 0.01 & 0.01 \\
\hline & & \multicolumn{6}{|c|}{ Non-grazed crop stubble (NGCS) } \\
\hline Korokoro & 100 & 1006 & 0.71 & 4.63 & 0.06 & 0.12 & 1.10 \\
\hline \multirow[t]{2}{*}{ Ramiha } & 43 & 196 & 0.14 & 1.16 & 0.02 & 0.20 & 0.16 \\
\hline & & \multicolumn{6}{|c|}{ Total annual loads } \\
\hline Korokoro & 135 & 1117 & 0.91 & 5.64 & 0.11 & 0.12 & 1.25 \\
\hline Ramiha & 55 & 204 & 0.17 & 1.32 & 0.02 & 0.22 & 0.18 \\
\hline
\end{tabular}


in relation to the GC and NGCS phases of the current study (95 versus $105 \mathrm{~mm}$ for the Korkoro soil and 18 versus $44 \mathrm{~mm}$ for the Ramiha soil, respectively), due to the Fransen et al. (2017) study experiencing a one in 80 -year rainfall event. Despite measuring similar runoff depths between the Fransen et al. (2017) and the GC and NGCS phases of the current study, 11 and 5 time the amount of suspended sediment, 1.8 and 2.4 times the amount of total $P$ and 3.9 and 4 times the amount of total $\mathrm{N}$ were measured in runoff from the Korokoro an Ramiha sub-ct winter cropping study. At the larger scale, stream loads of $134,0.52$ and $6.8 \mathrm{~g} /$ ha/day were measured fo suspended sediment, total $\mathrm{P}$ and total $\mathrm{N}$, respectively (Burkitt et al. (2016), and these values were orders of magnitude smaller than loads measured in the current cropping study. As many features of these studie were different perhaps this comparison can only be wualitative it is, however, illustrative. It would apper that the cropping of hill country have the potential to be high, suggesting winter cropping may elevate pollutant losses above losses commonly observed under other practices, even severe treading damage of pasture, which is ordinarily assumed to have a detrimental effect on the quality of runoff water. The marked relative increase in sediment loss, particularly from the Korokoro soil is noteworthy.

The results presented in the current study highlight the importance of applying active management to reduce sediment and nutrient loss from winter grazing of hill country crops. Further research is required to evaluate the advantages of alternative grazing options or mitigation measures, such as targeted grazing to maintain a buffer strip (Orchiston et al. 2013), grazing with a different stock class (i.e. sheep), maintaining higher ground cover or using shorter grazing times during high risk periods (McDowell et al. 2003a) in these hill country landscapes.

\section{Summary}

Grazing a winter crop on hill country resulted in large sediment and nutrient losses, particularly from the poorly drained soil. As the losses under winter cropping in hill country were larger than those measured at larger catchment scales, or those associated with other farm practices such as supplement feeding or grazing pasture in wet conditions, it is critical that these losses are minimised. This highlights the need for active managent to winter croping so as to redue inpacts on was from

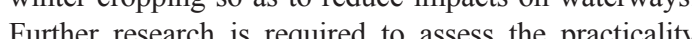

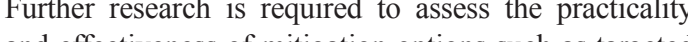
and effectiveness of mitigation options such as targeted grazing to maintain a buffer strip, grazing with a different stock class, maintaining higher ground cover and grazing for shorter periods of time when runoff risk is high.

\section{ACKNOWLEDGEMENTS}

The authors sincerely thank Jonathan Brophy from Massey University Agricultural Experiment Station Tuapaka for spraying, supply of cattle and supplement feed, $\mathrm{H} \& \mathrm{~T}$ Agronomics for valuable advice on sowing and management of the swede crop and Bob Toes and Ross Wallace for valuable technical assistance.

\section{REFERENCES}

Blakemore, L.C.; Searle, P.L.; Daly, B.K. 1972. Methods for chemical analysis of soils, NZ DSIR, New Zealand. pp. A1.1.

Burkitt, L.; Bretherton, M.; Singh, R.; Hedley, M. 2016. Comparing nutrient loss predictions using Overseer ${ }^{\circledR}$ and stream water quality in a hill country sub-catchment. In: Integrated nutrient and water management for sustainable farming. Eds. Currie, L.D.; Singh, R, Fertilizer and Lime Research Centre, Massey University, Palmerston North, New Zealand. 9 pp.

Fransen, P.; Burkitt, L.; Bretherton, M.; Horne, D.; Singh, R.; Hickson, R.; Morris, S. 2017. Selection of cattle supplement feeding areas to reduce nutrient and sediment loss in surface runoff from hill country. In: Science and policy: nutrient management challenges for the next generation. Eds. Currie, L.D; Hedley, M.J. Fertilizer and Lime Research Centre, Massey University, Palmerston North, New Zealand. 5 pp.

Hosomi, M.; Sudo, R. 1986. Simultaneous determination of total nitrogen and total phosphorus in freshwater samples using persulphate digestion. International Journal of Environmental Studies 27: 267-275.

McDowell, R.W. 2006. Phosphorus and sediment loss in a catchment with winter forage grazing of cropland by dairy cattle. Journal of Environmental Quality 35: 575-583.

McDowell, R.W.; Drewry, J.J.; Muirhead, R.W.; Paton, R.J. 2003a. Cattle treading and phosphorus and sediment loss in overland flow from grazed cropland. Soil Research 41: 1521-1532.

McDowell, R.W.; Drewry, J. Monaghan, R.M.; Condron, L.M. 2003b. Influence of soil treading on sediment and phosphorus losses in overland flow Australian Journal of Soil Research 41: 949-961.

Nguyen, M.L.; Sheath, G.W.; Smith, C.M.; Cooper, A.B. 1998. Impact of cattle treading on hill land: 2 Soil physical properties and contaminant runoff. New Zealand Journal of Agricultural Research 41: 279290.

Orchiston, T.S.; Monaghan, R.M.; Laurenson, S. 2013. Reducing overland flow and sediment losses . for of nutrients on arms. Eds. Currie, L.D.; Christensen, C.L. Fertilize and Lime Research Centre, Massey University, Palmerston North. pp. 1-7.

Silburn, D.M.; Carroll, C.; Ciesiolka, C.A.A.; deVoil, R.C.; Burger P. 2011. Hillslope runoff and erosion on duplex soils in grazing lands in semi-arid centra Queensland. I. Influences of cover, slope, and soil. Soil Research 49: 105-117.

Table 4 A comparison of sediment and nutrient losses ( $/$ /ha/day) as measured in three recent hill country studies conducted in close proximity on Massey University's Agricultural Experiment Station, Tuapaka.

\begin{tabular}{|c|c|c|c|c|c|}
\hline \multirow{2}{*}{$\begin{array}{l}\text { Study } \\
\text { Soil }\end{array}$} & \multirow{2}{*}{$\begin{array}{c}\begin{array}{c}\text { Catchment loss from an } 85 \text { ha } \\
\text { catchment draining study area } \\
\text { ( } \mathrm{g} / \mathrm{ha} / \mathrm{day})\end{array} \\
\text { Range of soil (including Korokoro and Ramiha) }\end{array}$} & \multicolumn{2}{|c|}{$\begin{array}{l}\text { Runoff losses from an area } \\
\text { damaged by treading } \\
\text { ( } / \text { /ha/day })\end{array}$} & \multicolumn{2}{|c|}{$\begin{array}{c}\text { Runoff losses associated } \\
\text { with GC and NGCS phases } \\
\text { (g/ha/day) }\end{array}$} \\
\hline & & Korokoro & Ramiha & Korokoro & Ramiha \\
\hline Sediment & 134 & 1,162 & 465 & 12,613 & 2,272 \\
\hline $\mathrm{P}$ & 0.52 & 5.1 & 0.70 & 9.4 & 1.7 \\
\hline $\mathrm{N}$ & 6.8 & 15.8 & 3.5 & 61 & 13.9 \\
\hline
\end{tabular}

\section{A Burkitt et al. (2016).}

